\title{
PRÁCE S ŽÁKY S ODLIŠNÝM MATEŘSKÝM JAZYKEM - SPOLUPRÁCE PEDAGOGICKO-PSYCHOLOGICKÉ PORADNY A ZÁKLADNÍ ŠKOLY
}

\author{
MAGDALÉNA VRBOVÁ
}

\begin{abstract}
Prezentována př́padová studie popisuje práci s žákem s odlišným mateřským jazykem v rámci současného stavu českého školství a legislativy a snaží se zaměřit pozornost na možné dopady práce s touto cílovou skupinou na jejich proces akulturace, začleňování do sociálního kolektivu, osobní pohodu, sebevědomí a další psychologické faktory, které s procesem akulturace souvisí.
\end{abstract}

Klíčová slova: odlišný mateřský jazyk, akulturace, osobní pohoda, sebevědomí, žáci, kazuistika

https://doi.org/10.14712/23366486.2017.11

\section{Úvodem}

Pro uvedení do kontextu problematiky práce s žáky s odlišným mateřským jazykem (dále jen $\mathrm{OMJ}$ ) je důležité uvést, proč je potřeba věnovat v dnešní době pozornost této skupině. Prvním důvodem je už samotný fakt, že na našem území dlouhodobě žijí různé skupiny cizinců a jejich počet každým rokem stoupá. Na území České republiky od roku 2004 do roku 2015 počet cizinců vzrostl o $82,7 \%$. V roce 2004 byl počet cizinců dle Českého statistického úřadu 255 917, v roce 2015 už 467562 (Vývoj počtu cizinců v ČR v letech 2004-2015, 2016). Předběžné čtvrtletní údaje ze zář́i 2016 udávají nárůst cizinců od prosince roku 2015 o víc než 20 000, na 487751 cizinců („Počet cizinců v ČR,“2016). Nejpočetnější skupinu cizinců na konci září 2016 tvořili Ukrajinci (108 533, 22,25 \%), dále Slováci (105 905, 21,71 \%), Vietnamci (57 841, 11,85 \%), Rusové (35 512, 7,28 \%), Němci (21 095, 4,32 \%), Poláci (20 216, 4,14 \%), 138649 (28,42\%) cizinců tvořili lidé ostatních státních příslušností (Počet cizinců v ČR - předběžné čtvrtletní údaje; 2004/06-2016/09, 2016).

Do skupiny téměř půl miliónu cizinců na území České republiky se samozřejmě započítávají i mladiství imigranti. Dle údajů Českého statistického úřadu se v různých typech škol (mateřské školy, základní a střední školy, konzervatoře, VOŠ, vysoké školy) ve školním roce 2015/2016 vzdělávalo 78365 cizinců. Na základních školách se vzdělávalo 880251 žáku, z toho 18281 žáků jiné než české státní př́islušnosti (Cizinci - vzdělávání, 2015). Údaje o tom, kolik z těchto žáků a studentů neovládá český jazyk na úrovni dostatečné pro zvládání vzdělávání ve školách, však nejsou známé. 
Jak ilustrují výše uvedená čísla, učitelé na základních školách se potýkají s velkou skupinou žáků cizinců a čím dál tím častěji s cizinci bez znalosti českého jazyka, kterým není možné zprostř̌edkovat učivo, protože nerozumí ani základním frázím každodenního života. Na jisté základní škole v Praze jsem se setkala s př́padem, kdy mladá dívka ve věku 13 let původem z Vietnamu, která byla v ČR druhým rokem, nerozuměla ani pokynům jako čekat, podat nebo jít dál. Už to, že neporozuměla těmto běžným instrukcím, jednak znemožňovalo práci učitelů a jednak zvyšovalo u těchto učitelů frustraci, co se odráželo na kvalitě spolupráce. Dívka byla proto poslána na vyšetření do pedagogicko-psychologické poradny pro podezření na poruchu řeči, protože se do té doby nebyla schopna naučit komunikovat $\mathrm{v}$ češtině. $\mathrm{V}$ poradně byla diagnostikována jako kulturně znevýhodněná žákyně a doporučením pro práci byly i hodiny českého jazyka pro cizince nad rámec běžné výuky. Tento př́pad není ojedinělý a ilustruje nejen pedagogickou část práce s těmito žáky, ale také dopad této práce na psychiku učitelů a žáků.

Cizinci, kteří přicházejí na naše území, se potýkají s procesem adaptace na nové prostředí. Specifické v tomto procesu je přizpůsobování se odlišnostem kultury hostitelské společnosti. Tato adaptace se nazývá akulturace a poprvé ji pojmenoval Redfield jako ,fenomén, který vzniká, když spolu neustále přicházeji do př́mého kontaktu skupiny z různých kultur a tento kontakt má za následek změny v pưvodnich kulturnich vzorcích jedné nebo obou skupin" 3 (Redfield et al., podle Johnson, 2011, s. 149). Tento proces se podle dané definice může dít obousměrně tj. obě skupiny se pod vlivem adaptace mění, i jednosměrně tj. skupina příchozích migrantů mění své zvyky, normy a další charakteristiky, přičemž majoritní kultura změnou neprochází, nebo je změna zanedbatelná (Berry, 2001; Graves, 1967; Smith \& Guerra, 2006). Na úrovni státu a české společnosti můžeme předpokládat jednosměrný proces akulturace. Naše zákony, tradice ani zvyky se pod vlivem příchozích menšin nebudou zásadně měnit. Na úrovni školního prostředí a jednotlivců, kteří přicházejí do přímého kontaktu s cizinci, se však může projevit i obousměrný proces akulturace, kdy členové majoritní skupiny, tedy české děti, mění své postoje na základě kontaktu s minoritní skupinou - cizinci ve třídě. Výzkumy akulturace se ale častěji zaměrují na minoritní skupiny, tedy cizince, proto, že v praxi je efekt vlivu kultury silnější na nedominantní skupinu a její členy (Berry, 2001).

Akulturační proces přináší pro cizince specificky akulturační stres. Jeho zdrojem jsou různé faktory, např́klad neporozumění jazyku hostitelské společnosti, rozdílné způsoby akulturace dětí a rodičů, vnímaná diskriminace (Ying, 1996; Gil et al., 1994; American psychological association, Presidential Task Force on Immigration, 2012) a kterého důsledky se můžou projevit v podobě narušení duševního zdraví (úzkosti, deprese apod.), pocitů marginalizace, odcizení či nízkého sebevědomí (Berry, Kim, Minde \& Mok, 1987; Kim \& Stoner, 2008; Rudmin, 2009). K tomuto stresu v prostředí školy přispívají i konkrétní obavy z př́itomnosti dětí cizinců na školách, které vycházejí z přesvědčení, že se učitel z důvodu nižší komunikační schopnosti dítěte musí věnovat víc právě těmto dětem, a také že přítomnost těchto dětí má negativní vliv na akademický výkon dětí domácích (Brunello, Rocco, 2013).

V prostředí školy působí pozitivně pozitivní vztahy se spolužáky, blízkost s vrstevníky, pozitivní hodnocení učiteli a rodiči, pocit školské spolupatřičnosti tj. sdílení hodnot,

[...] phenomena which results when groups of individuals having different cultures come into continuous first hand contact with subsequent changes in the original culture patterns of either or both groups. (Redfield et al., 1936, p. 149) 
postojů školy, aktivní začlenění se do tohoto prostředí (Hess \& Holloway, 1984; Grigoryeva \& Shamionov, 2014). Pocit školské spolupatřičnosti má dále vliv na zvýšení sociálního zapojení, motivace, školské docházky, akademického zapojení a dosahování výsledků u žáků (Hamre \& Pianta, 2001). Pro zmírnění projevů akulturačního stresu je v prostředí školy důležitý vztah s učiteli a dalšími pracovníky školy, kteří pomáhají překlenout propast mezi domácí a školskou kulturou a tvoří tak kulturní spojení s novou společností. Pozitivní vztah s těmito dospělými poskytuje emocionální podporu a pomoc mladým migrantům, kteří následně více participují na různých školských aktivitách, o které by za normálních okolností bez této podpory neprojevili zájem (American psychological association, Presidential Task Force on Immigration, 2012). Následující kazuistika se snaží ilustrovat právě tento vztah a dopad spolupráce na zmírnění obtíží ve škole jak v oblasti učení, tak po stránce akulturace a osobní pohody.

\section{Dan}

Dan, kluk vietnamské národnosti, narozen 10. 12. 2000, byl vychováván do svých 13 let ve Vietnamu. Spolu s matkou a otcem žil ve Vietnamu do svých 7 let, kdy odjel nejprve otec a následně, když bylo Danovi 9 let, odjela za otcem i jeho maminka do České republiky. Dan zůstal ve Vietnamu, kde se o něj starala babička. Do základní školy nastoupil v 5 letech (dle dostupných informací od rodičů ve Vietnamu nastupují do školy děti v tom roce, kdy dovrší 6 let věku, bez ohledu na to, jestli 6 let dovrší po začátku školního roku), péče během školní docházky byla podle otce velmi slabá. Dan ale ve škole neměl větší potíže, až v 6. ročníku s matematikou. Po odchodu otce ze země byl Dan uzavřenější, izolovanější, vyhledával méně kontaktů ve společnosti, rovněž méně mluvil. V době, kdy byl jen s babičkou, se sociální izolace prohloubila, babička Dana nepouštěla ven s kamarády, bála se o něj, vštěpovala mu, že svět ,,venku“ je nebezpečný. Dan sám ani tyto aktivity nevyhledával a postupem času to přijal. Ve Vietnamu dokončil 7. ročník školy a v létě roku 2013 odešel za rodiči do ČR. V České republice nastoupil v září 2013 opakovaně do 7. ročníku základní školy z důvodu usnadnění adaptace. Ve škole se učitelé domluvili s dalším vietnamským žákem, aby pomáhal Danovi překládat učivo i požadavky učitelů. Dan se ale za rok ve škole nerozmluvil, měl potíže i s dalšími předměty, přetrvával problém s matematikou. Během této doby nebyl klasifikován a následně byl ve většině předmětů hodnocen slovně. Znalost jazyka ale nebyla dostatečná, po pololetí nebylo možné Dana klasifikovat známkou, musel proto 7. třídu opakovat. Během podzimu školního roku 2014/2015 se škola rozhodla doporučit rodičům vyšetření v pedagogicko-psychologické poradně (dále jen PPP), protože Dan v rámci komunikace v českém jazyce nejevil žádané známky postupu.

Učitel, který zprostředkoval komunikaci se školou (dále pan učitel H.), se na začátku k situaci vyjádřil následovně: „Dan k nám do školy nastoupil zhruba před rokem a dosud se mu nepodařilo překlenout jazykovou bariéru - komunikuje velice úsporně či vůbec ne. Vzhledem k tomu byl přeřazen opět do sedmé tř́dy. Komunikační problém je jednak zpưsoben absenci jazykového vzoru v rodině, dále se domnívám, že by se mohlo jednat o komunikační blok na bázi mentálního deficitu či možné SPU (nebo jiné poruchy)." Škola zároveň požádala PPP o prodloužení možnosti slovního hodnocení pro Dana a stanovení doporučení pro integraci, nebo přímo doporučení na přestup do speciální školy, pokud tomu budou výsledky odpovídat. 
Dan navštívil PPP spolu s otcem a tlumočnicí (oba rodiče Dana česky nemluvili). Vyšetření začalo úvodní konzultací s otcem, Danem a tlumočnicí, přítomná byla psycholožka a speciální pedagožka. Dan během úvodního rozhovoru spontánně nekomunikoval, na otázky často odpovídal, že neví, nebo neodpověděl vůbec. I na otázku, co dělá ve volném čase, odpověděl, že neví. Tlumočnice potvrdila, že i ve vietnamštině má potíže s komunikací, vyslovuje špatně, často ani nerozumí tomu, co mu tlumočnice říká. Během psychologického vyšetření mohli být administrovány jen testy na zjištění názorové složky intelektu, byly použity standardní Ravenovy progresivní matrice (Raven, 1989). Instrukce byly velice názorné, Danovi bylo předvedeno, jak postupovat, i jak zapsat výsledek do záznamového archu. Porozumění instrukcím ale nebylo možné objektivně stanovit. Během práce pracoval nesystematicky, velmi chaoticky, pracovní tempo bylo pomalé. V testu dosáhl výsledku IQ $=88$, výsledek byl hodnocen jako orientační.

Speciálně pedagogické vyšetř̌ení bylo zaměřeno na čtení, porozumění čtenému textu a diktát. Pro ověrení porozumění čteného byl vybrán text Zajíček, doporučen pro konec 1. ročníku / první pololetí 2. ročníku (Matějček, Šturma et al., 1987). Pro ověření znalosti gramatiky byly vybrány věty z diktátů určených pro 1. stupeň ZŠS, v různé obtížnosti (Novák, 2002). Vyšetření potvrdilo jen povrchní znalost základních českých slov, nebyl schopen písemně se vyjádřit takovým způsobem, aby věty dávaly v češtině smysl. Psaní i čtení bylo mechanické, bez porozumění. Bylo doporučeno slovní hodnocení ve škole, individuální přístup (zohlednění pomalého pracovního tempa, užití názoru během výkladu, výklad co nejjednodušší formou, pomoc vietnamských spolužáků ve výuce, podpora rozvoje sociálních dovedností, začleňování do kolektivu, rodině byl doporučen i program neziskové organizace Hestia - Pět P, pro rozvoj sociálních dovedností mimo školu), zabezpečení individuální výuky češtiny a vytvoření individuálního vzdělávacího plánu na základě odlišného kulturního prostředí a aktuální životní situace.

Ve škole v této době proběhla schůzka s organizací META, která se zaměřuje na pomoc mladým migrantům v ČR. Danovi bylo doporučeno doučování, zprostředkováno právě touto organizací. Dan byl v tomto školním roce zařazen do třídy pana učitele H., který zpočátku odmítal práci s Danem, stavěl se k situaci negativně. Sám o tomto počátku práce s Danem řekl: „Na začátku jsem si uvědomil, že mne čeká hodně práce, proto jsem byl naštvaný." Nevěděl, co má s Danem dělat, jakým zpưsobem ho vzdělávat, když nerozumí ani základním frázím. Uvědomoval si však, že práce s cizinci vyžaduje jiný přístup než práce s českými žáky, vyžaduje víc práce ze strany učitele, protože systematická podpora v této oblasti v současné době pro učitele chybí. Na začátku v něm proto narůstala frustrace z nedostatku možností, omezeného prostoru na práci s Danem a následných komplikací, které s sebou tato situace přináší.

Jak už bylo výše zmíněno, zvládnutí jazyka hostitelské společnosti přispívá ke snižování akulturačního stresu a k celkově vyšší osobní pohodě těchto dětí, co se může dále pozitivně odrazit na jejich školním výkonu. Tj. tím, že podporujeme jazykovou př́pravu cizinců, přispíváme i ke zlepšování jejich adaptace a akulturace a celkově i k lepší sociální atmosféře $\mathrm{v}$ rámci kolektivu trrídy i v samotné škole. V praxi je ale podpora výuky českého jazyka jako cizího jazyka složitá. Legislativně tuto výuku upravuje $\$ 20$ a $\$ 16$ zákona č. 561/2004 Sb., ve znění účinném od 1. 1. 2017. Tyto hodiny ale z pohledu praxe nejsou dostatečné pro naplnění vzdělávacích potřeb těchto žáků. Chybí také vzdělávání pro pedagogy v oblasti problematiky žáků s OMJ a podpora vzdělávání učitelů v oblasti výuky češtiny pro cizince. Například na Univerzitě Karlově existuje bakalářský a navazující 
magisterský program - Čeština pro cizince, ale i dle slov pana učitele H. se jen velmi málo absolventů dostává do učitelské praxe např. na zmíněné základní školy.

Pan učitel H. se po počátečním šoku rozhodl začít vyhledávat možnosti právě pro Dana a následně i pro další jeho spolužáky cizince. Na škole pod záštitou magistrátu dané městské části Prahy vzniklo doučování češtiny pro cizince, kde ale pořád chyběli učebnice. Proto si pan učitel H. začal materiály na tyto hodiny nejprve připravovat sám a následně se přihlásil do kurzu výuky češtiny jako cizího jazyka pořádaného Ústavem jazykové a odborné přípravy UK. Pan učitel H. popisuje toto období z jeho pozice jako profesní obrat: „Opravdu jsem se do toho ponořil ... od naštváni a nechuti ... křičel jsem, že toho učit nebudu... já mám rád ve věcech systém, v tomto žádný nebyl (zákon), tak jsem si ten systém pro práci s cizinci udělal sám.“

Dan absolvoval hodiny češtiny pro cizince od poloviny 8. ročníku. Na začátku popisoval pan učitel H. komunikaci s Danem jako zátěž, dnes to vidí tak, že i když je pořád problém s Danem komunikovat, je tato vnímaná zátěž daleko menší než v počátcích. Dan už rozumí poslechu, i když se ještě neumí dobře samostatně vyjádřit.

Na začátku druhého pololetí 9. ročníku ve školním roce 2016/2017 byl Dan poslán na kontrolní vyšetření do PPP. Přišel na vyšetření v přítomnosti tlumočnice, s matkou. V komunikaci nastal velký posun, Dan mluvil během úvodního rozhovoru i samostatně bez tlumočnice, zvládl komunikovat informace o volném čase i základní informace o škole. V komunikaci přetrvávala stydlivost, ale působil víc sebejistě než u prvního setkání, byl veselý, zlepšil se i jeho postoj, seděl vzpř́ímeně, působil vyspěle a mnohem jistěji než před dvěma lety. Během vyšetření byl patrný posun k lepšímu i v oblasti pracovních návyků, Dan s prezentovaným testovým materiálem pracoval systematicky, velice pečlivě, klidně, v přiměřeném tempu. Pokud si s něčím neuměl poradit, tuto položku vynechal, aby neztrácel čas a na konci se k vynechaným položkám zas vrátil. Opět byly administrovány Ravenovy progresivní matrice (Raven, 1989), výsledek IQ = 93.

Během speciálně pedagogického vyšetření byl v rámci zkoušky čtení administrován opakovaně text Zajíček. Rychlost čtení se zlepšila, i když ve výsledku zůstala v podprůměrném pásmu vzhledem $\mathrm{k}$ věkové normě. Čtení s chybami (záměny/vynechávání/ přidávání písmen/slov, potíže s tvarově podobnými písmeny b/p/q), text nebyl schopen samostatně reprodukovat, ale dokázal si vybavit některé detaily příběhu (,On šel za maminkou, chtěl něco... běhat."). Diktát se opět skládal z vět různé obtížnosti určených pro první stupeň ZŠ. Zápis slov byl fonetický, s chybami v měkčení, diakritice. Porozumění se zlepšilo, rozuměl jednoduchým výrazům. (Příklad Danova zápisu: ,dnes je štreda a žitra bude zace čtvrtek $k^{6}$ ).

Ke komunikačním kompetencím Dana v pololetí 9. třídy se pan učitel H. v jeho písemném hodnocení vyjádřil takto: „Receptivni dovednosti - rozumí jednodušším typưm sdělení, ústních i písemných; plně rozumí instrukcím, časovým údajům. Produktivní a interaktivní dovednosti: sestaví jednodušši mluvená i písemná (latinkou) sdělení, konverzuje na běžná témata, přečte jednodušši text. Při (orientační!) aplikaci popisủ kategorizace „, Společného evropského referenčního rámce jazykü“ se komunikační dovednosti žáka nachází na hranici mezi kategoriemi Uživatel základů jazyka (A2) / Samostatný uživatel (B1).“

Danovi dle pana učitele H. pomohl i fakt, že měl o dva roky vzdělávání v základní škole navíc. O celé situaci řekl: „Před 2 lety by nikam nemohl, zůstal by doma, nezvládl by dalš́ školu... je tady šance, že jsme ušetřili státu penize na sociálních dávkách a dodali 
jsme cizince, který je schopen se integrovat, samostatně pracovat, žit, být platný člen společnosti.“

Dan byl panem učitelem $H$. pověřen už i k překládání základních informací dalším nově příchozím žákům vietnamské národnosti, kteří neměli žádnou nebo jen minimální znalost českého jazyka. Dan se dle vlastních slov dobře adaptoval, těší se na další školu, chce být v budoucnosti kuchařem, mít rodinu a plánuje nadále žít v České republice.

\section{Shrnutí}

Př́́pad Dana ukazuje jak potenciál, který má žák s OMJ tak i možnosti pro pedagogické pracovníky, jakým způsobem s tímto potenciálem pracovat. Danovi jazykové kompetence v češtině se zvýšili, čímž se zlepšila i schopnost komunikovat se spolužáky a následně i zapojení do kolektivu spolužákủ. Dan docházel na hodiny češtiny pro cizince spolu s dalšími spolužáky jiných národností, o kterých se Dan vyjádřil jako o kamarádech. Tento př́pad z praxe podporuje výše zmíněnou teorii, že znalost jazyka je podstatná pro následnou adaptaci a socializaci. Dan se rozvinul i po stránce pracovní, jeho pracovní návyky se zlepšily docházkou do české školy a intenzivnější péči ze strany učitelů i spolužákủ. Osobnostní rozvoj byl kvalitativně pozorován v Danově chování, kdy byl při druhé návštěvě v PPP sebejistý, komunikativní, veselý, i jeho držení těla a neverbální projevy komunikovali větší jistotu a sebevědomí v situaci. Na závěr je vhodné dodat, že i při limitovaných možnostech, které máme, $\mathrm{v}$ dnešní době v oblasti vzdělávání cizinců existují cesty, jak s těmito žáky pracovat a pomoct jim překlenout jazykovou bariéru a tím usnadnit nejenom proces učení, ale rovněž navazování vztahů jak s kamarády, tak $\mathrm{s}$ učiteli, a i existenci ve světě mimo prostředí školy. Přesně tak, jak se v tomto př́ípadu vyjádřil pan učitel H., je důležité učinit tento první krok, a to pomoci při získávání jazykových kompetencí, abychom usnadnili akulturační proces mladým cizincům, a takovým způsobem, aby se tito cizinci mohli stát platnými členy naší společnosti, plně adaptovaní na českou kulturu.

\section{LITERATURA}

American psychological association, Presidential Task Force on Immigration. (2012). Crossroads: The psychology of immigration in the new century. [Vyhledáno 30. 06. 2016 na http://www.apa.org/topics/immigration/ report.aspx]

Berry, J. W., Kim, U., Mindle, T., \& Mok, D. (1987). Comparative studies of acculturative stress. International Management Review, 21(1), 491-511.

Berry, J. W. (2001). A psychology of immigration. Journal of Social Issues, 57(3), 615-631.

Brunello, G., \& Rocco, L. (2013). The effect of immigration on the school performance of natives: Cross country evidence using PISA test scores. Economics of Education Review, 32, 234-246.

Cizinci - vzdělávání. (2015). [Vyhledáno 01. 02. 2017 na https://www.czso.cz/documents/11292/32508273 /c04R41_2015.pdf/56f9192a-1c83-48d0-8913-8be40488f29d?version=1.0]

Gil, A. G., Vega, W. A., \& Dimas, J. M. (1994). Acculturative stress and personal adjustment among Hispanic adolescent boys. Journal of Community Psychology, 22(1), 43-54.

Graves, T. D. (1967). Acculturation, access, and alcohol in a tri-ethnic community. American Anthropologist, 69, 306-321. 
Grigoryeva, M.V., \& Shamionov, R.M. (2014). Predictors of emotional well-being and academic motivation in junior schoolchildren. Procedia - Social and Behavioral Sciences, 146, 334-339.

Hamre, B., \& Pianta, R. (2001). Early teacher-child relationships and the trajectory of children's school outcomes through eighth grade. Child Development, 72, 625-638.

Hess, R.D., \& Holloway, S.D. (1984). Family and school as educational institutions. Review of child development research, 7, 179-222.

Johnson, T. M. (2011) Acculturation: Implications fot Individuals, Families and Societies. New York: Nova Science Publishers, Inc.

Kim, H., \& Stoner, M. (2008). Burnout and turnover intention among social workers: Effects of role stress, job autonomy, and social support. Administration in Social Work, 32, 5-25.

Matějček, Z., Šturma, J., Vágnerová, \& M., Žlab, Z. (1987). Zkouška čtení. Bratislava: Psychodiagnostické a didaktické testy.

Novák, J. (2002). Diagnostika specifických poruch učeni. Brno: Psychodiagnostika. Počet cizinců v ČR - předběžné čtvrtletni údaje; 2004/06-2016/09. (2016). [Vyhledáno 01. 02. 2017 na https://www.czso.cz/documents /11292/27320905/c01R02_201609.pdf/adcd7705-225e-4bb5-ab8c-a444def989e3?version=1.0]

Raven, J. C. (1989). Progresívne matrice. Bratislava: Psychodiagnostické a didaktické testy, n. p.

Rudmin, F. W. (2009). Constructs, measurements and models of acculturation and acculturative stress. International Journal of Intercultural Relations, 33, 106-123.

Smith, E. P., \& Guerra, N. (2006). Preventing youth violence in a multicultural society. Washington, D. C.:American Psychological Association.

Vývoj počtu cizincu v $\breve{C} R$ v letech $2004-2015$ (stav k 31. 12.). (2016). [Vyhledáno 01. 02. 2017 na https://www.czso. cz/documents/11292/41862280/c01R01_2015.pdf/48b91796-0832-4b4a-b5fb-92e23937a9e5?version=1.0]

Ying, Y. W. (1996). Immigration satisfaction of Chinese Americans: An empirical examination. Journal of Community Psychology, 24(1), 3-16.

Zákon 561/2004 Sb. o předškolním, základním, středním, vyšším odborném a jiném vzdělávání (školský zákon).

\title{
WORK WITH PUPILS WITH A DIFFERENT MOTHER TONGUE - COOPERATION BETWEEN PEDAGOGICAL-PSYCHOLOGICAL COUNSELING CENTER AND ELEMENTARY SCHOOLS
}

\author{
M. VRBOVÁ
}

\section{ABSTRACT}

The presented case study describes the work with a pupil with a different mother tongue in the current state of Czech education and legislation. It tries to focus attention on the possible impacts of working with this target group on their process of adaptation on the culture, social inclusion, personal well-being, self-confidence and other psychological factors, which are related to the process of acculturation.

Key words: different mother tongue, acculturation, personal well-being, self-confidence, pupils, case study

O autorce: Mgr. et Bc. Magdaléna Vrbová, Pedagogicko-psychologická poradna pro Prahu 1, 2 a 4.E-mail: magdalena.vrba@gmail.com. 